\title{
SISTEM PENDUKUNG KEPUTUSAN \\ PENGUSULAN KENAIKAN PANGKAT BERBASIS WEB PADA KANTOR CAMAT SUNGAI SEMBILAN
}

\author{
Nur Rubiati ${ }^{1}$, Rahmad Kurniawan ${ }^{2}$, Elisawati $^{3}$, Sri Wahyuni ${ }^{4}$ \\ ${ }^{1,2,3,4}$ Sekolah Tinggi Manajemen Informatika \& Komputer (STMIK) Dumai \\ Jln. Utama Karya Bukit Batrem Dumai-Riau Kode Pos 28811 \\ e-mail : nurrubiati0412@ gmail.com ${ }^{1}$.rahmad0412@ gmail.com ${ }^{2}$, \\ elisawati06@gmail.com ${ }^{3}$, sriw55442@ gmail.com ${ }^{4}$
}

\begin{abstract}
ABSTRAK
Kantor Camat Sungai Sembilan menerapkan pengusulan kenaikan pangkat Aparatur Sipil Negara (ASN) yang dilakukan atau diusulkan dalam jangka waktu empat tahun sekali. Dalam proses pengusulan kenaikan pangkat, pegawai harus melengkapi seтиa berkas persyaratan dan proses peniliaian dari beberapa subkriteria. Dalam proses penilaiannya masih terdapat kendala-kendala di antaranya data masih manual, banyaknya kriteria yang dinilai satu persatu dengan jumlah pegawai yang banyak membutuhkan waktu cukup lama dalam pengolahan datanya. Oleh karena itu pengusulan penilaian pegawai kenaikan pangkat menggunakan sistem pendukung keputusan dengan menggunakan metode yang profile matching. Kriteria dan subkriteria yang digunakan pada sistem pendukung keputusan pengusulan kenaikan pangkat ini adalah kriteria sasaran kerja dan perilaku kerja dengan subkriteria sasaran kerja pegawai, kegigihan, otoritas pelayanan, integritas, komitmen, disiplin, kerjasama, kepemimpinan. Dengan adanya sistem ini, diharapkan dapat membantu setiap kepala bagian dalam proses pengusulan penilaian para pegawai pada Kantor Camat Sungai Sembilan sesuai kriteria yang ditentukan.
\end{abstract}

Kata kunci : Kenaikan Pangkat, Pemrograman PH, Profile Matching, SPK

\begin{abstract}
The Sungai Sembilan Sub-district Office implements proposals for promotion of the rank of the State Civil Apparatus (ASN) which are carried out or proposed within a period of four years. In the process of proposing a promotion, employees must complete all the requirements documents and the assessment process of several sub-criteria. In the assessment process there are still obstacles, including manual data, the number of criteria that are assessed one by one with the large number of employees who require a long time to process the data. Therefore, the proposal for employee appraisal for promotion uses a decision support system using a profile matching method. The criteria and sub-criteria used in the decision support system for proposing promotion are the criteria for work objectives and work behavior with sub-criteria for employee work targets, persistence, service authority, integrity, commitment, discipline, cooperation, leadership. With this system, it is hoped that it can assist each division head in the process of proposing an assessment of employees at the Sungai Sembilan Sub-district Office according to the specified criteria.
\end{abstract}

Keywords: Promotion, PH Programming, Profile Matching, DSS

\section{PENDAHULUAN}

Kenaikan pangkat merupakan salah satu hak yang diterima oleh para pegawai dalam hal ini Pegawai Negeri Sipil (PNS) atau lebih dikenal sekarang dengan Aparatur Sipil Negara (ASN), yakni penghargaan yang diberikan atas prestasi kerja dan pengabdiannya. Kantor Camat Sungai
Sembilan menerapkan kenaikan pangkat yang dilakukan atau diusulkan dalam jangka waktu empat tahun sekali. Dalam proses pengusulan kenaikan pangkat, pegawai harus melengkapi semua berkas persyaratan. Selain itu pegawai dinilai dari beberapa subkriteria tetapi dalam proses penilaiannya masih terdapat kendala- 
IN F ORMA TIK

Jurnal Informatika, Manajemen dan Komputer, Vol. 12 No. 2, Desember 2020

eISSN : 2580-3042

pISSN : 1979-0694

kendala di antaranya data masih manual, banyaknya kriteria yang dinilai satu persatu dengan jumlah pegawai yang banyak membutuhkan waktu cukup lama dalam pengolahan datanya.

Pengusulan kenaikan pangkat yang berbasis web menggunakan bahasa pemrograman Hypertext Prepocessor (PHP) untuk penanganan pembuatan dan pengembangan sebuah situs web tersebut, dan database yang digunakan MySQL yang mendukung dalam pengolahan data. Dengan adanya sistem ini, diharapkan dapat membantu setiap kepala bagian dalam proses penilaian pegawai pada Kantor Camat Sungai Sembilan sesuai kriteria yang ditentukan. Metode yang digunakan untuk mendukung sistem pengusulan kenaikan pangkat ini yaitu metode profil matching. Menurut Kusrini (2007:53) didalam jurnal (Kristiana, 2015) Profil Matching adalah sebuah mekanisme pengambilan keputusan dengan mengasumsikan bahwa terdapat tingkat variabel prediktor yang ideal yang harus dimiliki oleh pelamar, bukannya tingkat minimal yang harus dipenuhi atau dilewati. Dengan demikian setiap kepala bagian dapat menentukan penilaian pegawai yang akan melakukan pengusulan kenaikan pangkat.

Menurut (Kadir, 2014:108) Sistem

Pendukung Keputusan (SPK) atau Decision Support Systems (DSS) adalah sistem informasi interaktif yang menyediakan informasi, pemodelan, dan pemanipulasian data yang digunakan untuk membantu pengambilan keputusan pada situasi yang semiterstruktur dari situasi yang tidak terstruktur dimana tak seorang pun tahu secara pasti bagaimana keputusan seharusnya dibuat.

Menurut Syamsul (2012:56) dalam jurnal (Erdawati, Arie Linarta, Sukri Adrianto, 2016), Sistem pendukung keputusan terdiri dari 3 (tiga) komponen utama atau subsistem yaitu :

1. Subsistem Data (Database) Subsistem data merupakan komponen sistem pendukung keputusan penyedia data bagi sistem. Data yang dimaksud disimpan dalam suatu pangkalan data (database) yang diorganisasikan oleh suatu sistem yang disebut dengan sistem manajemen pangkalan data (Data Base Management System = DBMS). Melalui DBMS inilah data dapat diambil dan dievakuasi dengan cepat. Pangkalan data dalam sistem pendukung keputusan berasal dari dua sumber yaitu sumber internal (dari dalam perusahaan) dan sumber eksternal (dari luar perusahaan). Data

eksternal ini sangat berguna bagi manajemen dalam mengambil keputusan.

2. Subsistem Model (Model Base) Keunikan sistem pendukung keputusan adalah kemampuan dalam mengintegrasikan data dengan model-model keputusan. Model adalah suatu peniruan dari alam nyata. Kendala yang sering dihadapi dalam merancang suatu model adalah bahwa model yang disusun ternyata tidak mampu mencerminkan seluruh variable alam nyata. Sehingga keputusan yang diambil didasarkan pada model tersebut menjadi tidak akurat dan tidak sesuai dengan kebutuhan. Oleh karena itu dalam menyimpan berbagai model pada sistem pangkalan model harus tetap dijaga fleksibelitasnya. Hal lain yang perlu diperhatikan adalah pada setiap model yang disimpan hendaknya ditambahkan rincian keterangan dan penjelasan yang komperherensif mengenai model yang dibuat, sehingga pengguna atau perancang:

a. Mampu membuat model yang baru dengan mudah dan cepat.

b. Mampu mengakses dan mengintegrasikan sub rutin model.

c. Mampu menghubungkan model dengan model lain melalui pangkalan data.

d. Mampu mengelola model base dengan fungsi manajemen yang analog dengan manajemen database.

3. Subsistem Dialog (User Sistem Interface) Keunikan lain dari sistem pendukung keputusan adalah adanya fasilitas yang mampu mengintegrasikan sistem yang terpasang dengan pengguna secara interaktif. Fasilitas atau subsistem ini dikenal sebagai subsistem dialog, inilah sistem diartikulasikan dan diimplimentasikan sehingga pengguna atau pemakai dapat berkomunikasi dengan sistem yang dirancang.

Menurut jurnal (Idria Maita, 2011) Pangkat adalah kedudukan yang menunjukkan tingkat seorang pegawai negeri sipil berdasarkan jabatannya dalam rangkaian susunan kepegawaian dan digunakan sebagai dasar penggajian. Sedangkan kenaikan pangkat adalah penghargaan yang diberikan atas prestasi kerja dan pengabdian pegawai neger sipil terhadap Negara. Kenaikan pangkat dilaksanakan berdasarkan sistem kenaikan pangkat reguler dan sistem kenaikan pangkat pilihan.

Menurut jurnal (Artoni, 2006) Yang dimaksud kenaikan pangkat penghargaan yang diberikan atas prestasi kerja dan pengabdian 
IN F ORMA T IK A

Jurnal Informatika, Manajemen dan Komputer, Vol. 12 No. 2, Desember 2020

eISSN : 2580-3042

pISSN : 1979-0694

Pegawai Negeri Sipil terhadap Negara. Peraturan Pemerintah dan Pasal-pasal yang menetapkan Pegawai Negeri Sipil berhak naik pangkat atas pengabdian dan prestasi kerjanya pada Negara yaitu :

1. Peraturan Pemerintah Nomor 3 Tahun 1980 tentang Pengangkatan dalam Pangkat Pegawai Negeri Sipil.

2. Surat Edaran Kepala BKN Nomor 05/SE/1980 tentang Pengangkatan dalam Pangkat Pegawai Negeri Sipil.

Kenaikan Pangkat terbagi dua yaitu :

1. Kenaikan Pangkat Reguler adalah penghargaan yang diberikan kepada Pegawai Negeri Sipil yang telah memenuhi syarat ditentukan tanpa terikat pada jabatan.

2. Kenaikan Pangkat Pilihan adalah kepercayaan dan penghargaan yang diberikan kepada Pegawai Negeri Sipil atas prestasi kerjanya yang tinggi.

Jadi kenaikan pangkat adalah sebuah penghargaan yang diberikan kepada pegawai negeri sipil.

Langkah-langkah metode profile matching yaitu :

1. Pemetaan Gap Kompetensi Gap $=$ Profil Pegawai - Profil pangkat

2. Pembobotan

Setelah diperoleh gap pada masing-masing pegawai, setiap profil pegawai diberi bobot nilai dengan patokan tabel bobot nilai gap.

3. Perhitungan dan Pengelompokan Core dan Secondary Factor

Setelah menentukan bobot nilai gap untuk setiap aspek, kemudian setiap aspek dikelompokan menjadi 2 kelompok, yaitu kelompok Core Factor dan Secondary Factor. Pengelompokan core factor ditunjukkan

menggunakan rumus: $N C F=\frac{\sum N C}{\sum I C}$

Keterangan :

NCF : Nilai rata-rata core factor

NC : Jumlah total nilai core factor

IC : Jumlah item core factor

Sementara itu, perhitungan secondary factor bisa ditunjukkan dengan rumus berikut :

$N S F=\frac{\sum N S}{\sum I S}$

Keterangan :

NSF : Nilai rata-rata secondary factor

NS : Jumlah total nilai secondary factor

IS : Jumlah item secondary factor

4. Perhitungan Nilai Total

Dari hasil perhitungan setiap aspek, berikutnya dihitung nilai total berdasarkan persentase dari core dan secondary yang diperkirakan berpengaruh terhadap kinerja tiap- tiap profil. Penghitungan bisa dilihat pada rumus berikut :

$N=(x) \% N C F+(x) \% N S F$

Keterangan :

$\mathrm{N} \quad$ : Nilai Total dari aspek

(x)\% : Nilai Persen yang diinputkan

NCF : Nilai rata-rata Core Factor

NSF : Nilai rata-rata Secondary Factor

5. Perhitungan Penentuan Ranking

Hasil akhir dari proses profile matching adalah ranking dari kandidat. Penentuan ranking mengacu pada hasil perhitungan tertentu dengan aspek yang dicontohkan. Contoh perhitungan tersebut bisa ditunjukkan dengan rumus berikut : Rangking $=$ $(x) \% N i+(x) \% N s+(x) \% N p$

Keterangan :

$\mathrm{Ni}$ : Nilai kapasitas intelektual

Ns : Nilai sikap kerja

$\mathrm{Np} \quad$ : Nilai perilaku

$(\mathrm{x}) \%$ : Nilai Persen yang diinputkan

Setelah kandidat mendapat hasil akhir, maka bisa ditentukan peringkat atau ranking dari kandidat berdasarkan pada semakin besa(m.19a nilai hasil akhir sehingga semakin besar pula kesempatan untuk menduduki peringkat teratas, begitu pula sebaliknya.

Menurut (Setiawan, 2018:54) PHP sendiri sebenarnya merupakan singkatan dari "Hypertext Preprocessor", yang merupakan sebuah bahasa scripting tingkat tinggi yang dipasang pada dokumen HTML. Sebagian besar sintaks dalam php mirip dengan bahasa $\mathrm{C}$, java dan Perl, namun pada PHP ada beberapa fungsi yang lebih spesifik. Sedangkan tujuan utama dari penggunaan bahasa ini adalah untuk memungkinkan perancangan web yang dinamis dan dapat bekerja secara otomatis.

Menurut (Priyanto Hidayatullah, 2014:232) PHP sudah menjadi bahasa scripting umum yang banyak digunakan dikalangan developer web. Mempunyai banyak kelebihan menjadi alasasan utama kenapa PHP lebih dipilih sebagai basis umum dalam membuat sebuah web.

Menurut (Ignas, 2014:33) PHP merupakan bahasa berbentuk script yang ditempatkan di dalam server baru kemudian diproses. Kemudian hasil pemrosesan dikirimkan kepada web browser klien. Bahas pemrograman ini dirancang khusus untuk membentuk web dinamis. Artinya, pemrograman PHP dapat membentuk suatu 
IN F ORMA T IK A

Jurnal Informatika, Manajemen dan Komputer, Vol. 12 No. 2, Desember 2020

eISSN : 2580-3042

pISSN : 1979-0694

tampilan berdasarkan permintaan terkini. PHP dikenal sebagai bahasa pemrograman web, terutama dilingkungan Linux. Tetapi sebenarnya, PHP juga dapat digunakan pada server-server yang berbasis UNIX, Windows NT, Windows 95/98, dan Macintosh.

Menurut (Dahlan, 2013:1) istilah Web atau Website adalah merupakan kumpulan halaman yang menampilkan informasi data, teks, gambar, data animasi, suara, ataupun gabungan semuanya, baik yang besifat statis maupun yang bersifat dinamis yang membentuk suatu rangkaian yang saling terkait dengan jaringan-jaringan halaman (hyperlink) lainnya, diibaratkan suatu bangunan yang saling terkait antara rangkaian-rangkaian yang menguatkannya sehingga bangunan tersebut menjadi kokoh dan bagus.

Menurut Tim EMS (2012: 1) dalam jurnal (Eli Tri Sulis Setia Rini, 2018) Website adalah kumpulan halaman web yang diletakan dalam satu tempat/site/situs. Jadi, di dalam website terdapat halaman-halaman web, beserta file-file pendukungnya yang diletakan dalam satu tempat yang diidentifikasi melalui nama domain (domain name) dan alamat ip ( IP address)..

\section{METODOLOGI PENELITIAN}

Adapun langkah-langkah yang digunakan dalam membuat sistem dengan metode waterfall untuk menggambarkan rangkaian ide yang disusun secara sistematis, logis, jelas dan terstruktur sebagai berikut

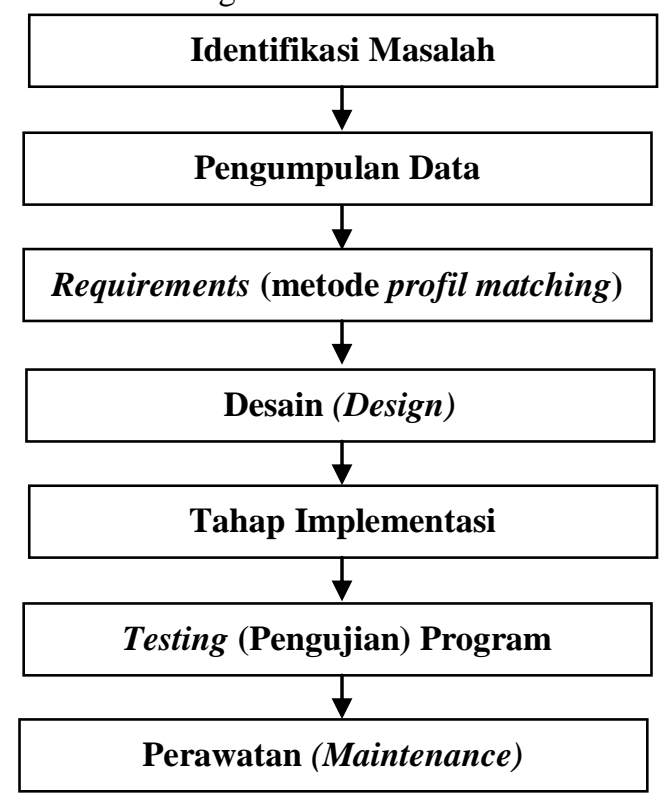

Gambar 1. Kerangka Kerja

Penjelasan dari langkah-langkah rangkaian ide diatas yaitu :

1. Identifikasi Masalah

Tahap pertama yang dilakukan dalam penelitian adalah mengetahui persoalan atau masalah apa yang sedang dihadapi oleh Kantor Camat Sungai Sembilan dalam melakukan proses penilaian pegawai yang akan melakukan pengusulan kenaikan pangkat.

2. Pengumpulan Data

Tahap selanjutnya adalah pengumpulan data yang berhubungan masalah yang telah diketahui dengan menggunakan metode yang dilakukan dalam penelitian ini yaitu:

a. FieldResearch (Penelitian Lapangan)

Penelitian ini dilakukan dengan pengamatan langsung ke lapangan tempat penelitian untuk mendapatkan informasi yang diperlukan. Dalam pengumpulan informasi digunakan teknik sebagai berikut :

1. Teknik Wawancara

Teknik wawancara dalam penulisan ini adalah melakukan wawancara pegawai Kepala Bagian Tata Usaha pada Kantor Camat Sungai Sembilan. Sehingga dari wawancara yang dilakukan dapat mengetahui permasalahan dalam proses penilaian pegawai yang akan melakukan pengusulan kenaikan pangkat masih secara manual.

2. Observasi

Observasi adalah metode pengumpulan data dengan cara melakukan pengamatan dan pencatatan langsung pada tempat penelitian atau pihak-pihak yang terkait dalam penelitian. Pada tahap ini peneliti melakukan pengamatan langsung ke Kantor Camat Sungai Sembilan.

b. LibraryResearch ( Penelitian Perpustakan) Penelitian ini dilakukan dengan cara mengumpulkan data dan mempelajarinya yang berupa teori-teori yang bersumber dari berbagai referensi, jurnal yang diambil dari internet yang sudah memiliki ISSN maupun sumber lainnya yang berhubungan dengan permasalahan yang akan diteliti.

\section{Requirements}

Tahap ini merupakan proses penelusuran atau pencarian syarat-syarat atau keperluan yang berhubungan dengan teknik-teknik dalam pembangunan sistem. Dalam tahap ini dapat dikumpulkan data-data proses pengusulan kenaikan pangkat pegawai, data-data itu seperti 
IN F O R M A I I A

Jurnal Informatika, Manajemen dan Komputer, Vol. 12 No. 2, Desember 2020

eISSN : 2580-3042

pISSN : 1979-0694

kriteria-kriteria yang diperlukan dalam penilaian.

Data yang diperoleh kemudian diproses, dan diuji untuk mengetahui masalah yang ada. Dari kriteria yang didapat dapat ditentukan metode yang akan dipakai yaitu metode profil matching.

Menurut Kusrini (2007:53) dalam jurnal (Kristiana, 2016) langkah-langkah metode profile matching yaitu :

a. Pemetaan Gap Kompetensi

b. Pembobotan

c. Perhitungan dan Pengelompokan Core dan Secondary Factor

d. Perhitungan Nilai Total

e. Perhitungan Penentuan Ranking

4. Desain (Design)

Meliputi perancangan desain interface yang akan digunakan sebagai fasilitas dialog antara sistem dan user.

5. Tahap Implementasi

Berguna untuk merubah proses perancangan sistem ke dalam bahasa pemrograman Hypertext Prepocessor (PHP) dengan menentukan beberapa form serta tabel yang dibutuhkan dalam proses pembuatan yang saling ada keterkaitan kriteria atau syarat yang telah ada.

6. Testing (Pengujian) Program

a. Black Box Test merupakan pengujian program yang dilakukan dengan mengamati keluaran dengan berbagai masukan.

7. Perawatan (Maintenance)

Merupakan tahap pemeliharaan dari sistem yang telah dibangun. Pemeliharaan dapat berupa perbaikan maupun pemeliharaan yang bersifat menambah atau mengurangi sistem sesuai dengan kebutuhan pengguna.

\section{HASIL DAN PEMBAHASAN}

a. Analisa Perhitungan Manual Metode Profile Matching

Untuk memperoleh penilaian pegawai yang akan melakukan pengusulan kenaikan pangkat maka Kantor Camat Sungai Sembilan menetapkan kriteria dan sub kriteria penilaian kepada pegawai Kantor Camat Sungai Sembilan. Berikut tahapan yang dilakukan untuk melakukan penilaian pengusulan kenaikan pangkat menggunakan metode Profil Matching yaitu :

1. Pemetaan Gap Kompetensi

Tabel 1. Kriteria

\begin{tabular}{|c|c|c|c|}
\hline $\begin{array}{c}\text { Kriteria } \\
\text { Penilaian }\end{array}$ & $\begin{array}{c}\text { Nama } \\
\text { Subkriteria }\end{array}$ & $\begin{array}{c}\text { Sub } \\
\text { krite } \\
\text { ria }\end{array}$ & $\begin{array}{c}\text { Standar } \\
\text { Kompete } \\
\text { nsi }\end{array}$ \\
\hline $\begin{array}{c}\text { Kriteria } \\
\text { Sasaran } \\
\text { Kerja } \\
60 \%\end{array}$ & $\begin{array}{c}\text { Sasaran kerja } \\
\text { pegawai }\end{array}$ & C1 & 5 \\
\cline { 2 - 4 } & Kegigihan & C2 & 5 \\
\hline
\end{tabular}

\begin{tabular}{|c|c|c|c|}
\hline \multirow{4}{*}{\begin{tabular}{c} 
Kriteria \\
Perilaku \\
\cline { 2 - 4 } $\begin{array}{c}\text { Kerja } \\
40 \%\end{array}$
\end{tabular}} & $\begin{array}{c}\text { Orientasi } \\
\text { Pelayanan }\end{array}$ & C3 & 5 \\
\cline { 2 - 4 } & Integritas & C4 & 4 \\
\cline { 2 - 4 } & Domitmen & C5 & 5 \\
\cline { 2 - 4 } & Kerjasiplin & C6 & 5 \\
\cline { 2 - 4 } & $\begin{array}{c}\text { Kepemimpina } \\
\mathrm{n}\end{array}$ & $\mathrm{C} 7$ & 4 \\
\hline
\end{tabular}

Tabel 2. Penilaian Pegawai

\begin{tabular}{|c|c|c|c|c|c|c|c|c|c|}
\hline \multirow{2}{*}{$\begin{array}{c}\text { O } \\
\text { O }\end{array}$} & $\begin{array}{c}\text { Pama } \\
\text { ai }\end{array}$ & 1 & 2 & 3 & 4 & 5 & 6 & 7 & 8 \\
\hline 1 & $\begin{array}{c}\text { Yulian } \\
\text { a }\end{array}$ & 5 & 5 & 4 & 4 & 4 & 4 & 4 & 4 \\
\hline 2 & Romas & 4 & 4 & 4 & 5 & 4 & 4 & 5 & 4 \\
\hline 3 & Krifni & 5 & 5 & 4 & 4 & 5 & 4 & 4 & 4 \\
\hline 4 & $\begin{array}{c}\text { Tajul } \\
\text { Arifin }\end{array}$ & 5 & 5 & 4 & 5 & 4 & 4 & 4 & 4 \\
\hline 5 & $\begin{array}{c}\text { Said } \\
\text { Ibrahi } \\
\text { m }\end{array}$ & 4 & 4 & 5 & 4 & 4 & 4 & 4 & 5 \\
\hline 6 & $\begin{array}{c}\text { Syafri } \\
\text { anto }\end{array}$ & 4 & 4 & 4 & 5 & 4 & 4 & 4 & 5 \\
\hline 7 & $\begin{array}{c}\text { Kamar } \\
\text { rozam } \\
\text { an }\end{array}$ & 4 & 4 & 5 & 4 & 4 & 5 & 4 & 5 \\
\hline 8 & $\begin{array}{c}\text { Siti } \\
\text { arivah }\end{array}$ & 4 & 4 & 4 & 4 & 5 & 4 & 4 & 4 \\
\hline 9 & $\begin{array}{c}\text { Adi } \\
\text { Wibo } \\
\text { wo }\end{array}$ & 4 & 4 & 4 & 5 & 4 & 4 & 5 & 5 \\
\hline 10 & $\begin{array}{c}\text { Ita } \\
\text { Rosita }\end{array}$ & 4 & 4 & 4 & 4 & 4 & 4 & 4 & 4 \\
\hline
\end{tabular}

Dari tabel 1 kiteria dan tabel 2 penilaian pegawai maka dapat dilakukan pencarian pemetaan gap kompetensi dengan rumus yaitu:

$\mathrm{GAP}=\mathrm{Cn}-$ standar kompetensi

Keterangan : $\mathrm{Cn}=$ subkriteria 
IN F ORM T IKA

Jurnal Informatika, Manajemen dan Komputer, Vol. 12 No. 2, Desember 2020

eISSN : 2580-3042

pISSN : 1979-0694

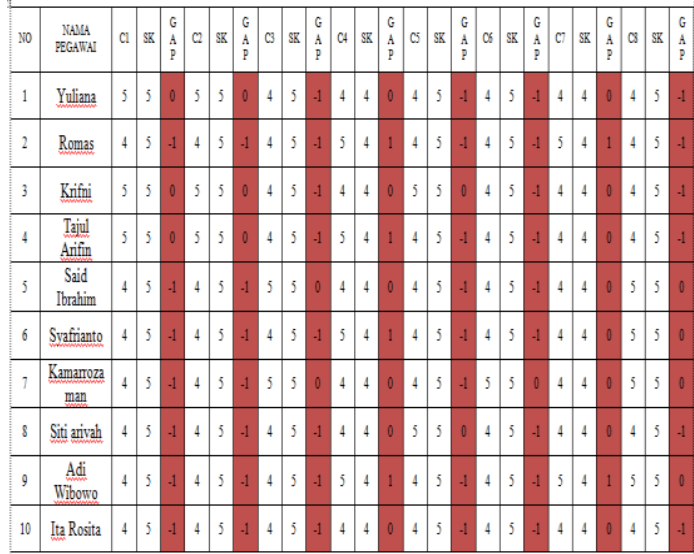

Gambar 2. Hasil Gap

Keterangan:

SK : Standar Kompetensi

C1, C2, C3, C4, C5, C6, C7, C8 : Subkriteria

GAP : hasil pengurangan nilai subkriteria dengan standar kompetensi

\section{Pembobotan}

Tabel 3. Bobot Nilai Gap

\begin{tabular}{|c|c|c|c|}
\hline No & Selisih & $\begin{array}{l}\text { Bobot } \\
\text { Nilai }\end{array}$ & Keterangan \\
\hline 1 & 0 & 5 & $\begin{array}{l}\text { Tidak ada selisih } \\
\text { (kompetensi sesuai } \\
\text { dengan yang } \\
\text { dibutuhkan) }\end{array}$ \\
\hline 2 & 1 & 4,5 & $\begin{array}{c}\text { Kompetensi individu } \\
\text { kelebihan } 1 \\
\text { tingkat/level }\end{array}$ \\
\hline 3 & -1 & 4 & $\begin{array}{c}\text { Kompetensi individu } \\
\text { kekurangan } 1 \\
\text { tingkat/level }\end{array}$ \\
\hline 4 & 2 & 3,5 & $\begin{array}{c}\text { Kompetensi individu } \\
\text { kelebihan } 2 \\
\text { tingkat/level }\end{array}$ \\
\hline 5 & -2 & 3 & $\begin{array}{c}\text { Kompetensi individu } \\
\text { kekurangan } 2 \\
\text { tingkat/level }\end{array}$ \\
\hline 6 & 3 & 2,5 & $\begin{array}{c}\text { Kompetensi individu } \\
\text { kelebihan } 3 \\
\text { tingkat/level }\end{array}$ \\
\hline 7 & -3 & 2 & $\begin{array}{c}\text { Kompetensi individu } \\
\text { kekurangan } 3 \\
\text { tingkat/level }\end{array}$ \\
\hline 8 & 4 & 1,5 & $\begin{array}{c}\text { Kompetensi individu } \\
\text { kelebihan } 4 \\
\text { tingkat/level }\end{array}$ \\
\hline 9 & -4 & 1 & $\begin{array}{c}\text { Kompetensi individu } \\
\text { kekurangan } 4 \\
\text { tingkat/level }\end{array}$ \\
\hline
\end{tabular}

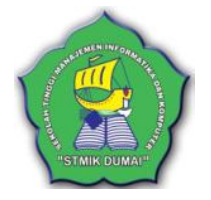

Dari Gambar 2 hasil gap dan tabel 3 bobot nilai gap yang dijadikan patokan dapat diperoleh bobot nilai pegawai seperti tabel berikut:

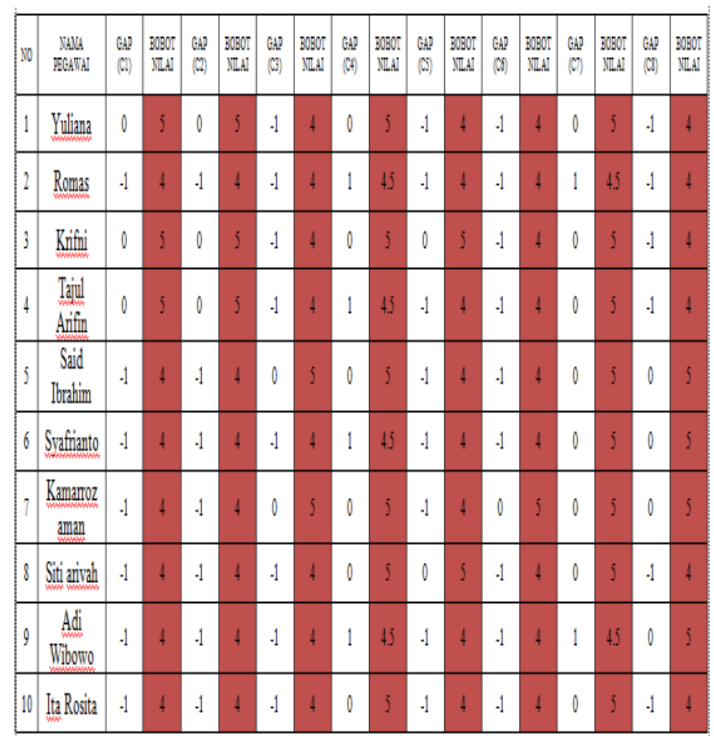

Gambar 3. Hasil Pemobobotan

3. Pengelompokan Dan Perhitungan Core Factor serta Secondary Factor

Untuk melakukan perhitungan core factor dan secondary factor terdapat tabel pengelompokkan jenis subkriteria yang akan menjadi prioritas utama dan subkriteria pendukung sebagai acuan perhitungan terhadap kriteria sasaran kerja dan perilaku kerja.

Tabel 4. Jenis Sub Kriteria

\begin{tabular}{|c|c|c|c|}
\hline $\begin{array}{l}\text { Kriteria } \\
\text { Penilaian }\end{array}$ & Subkriteria & $\begin{array}{c}\text { Nama } \\
\text { Subkriteria }\end{array}$ & Jenis \\
\hline \multirow{2}{*}{$\begin{array}{c}\text { Kriteria } \\
\text { Sasaran } \\
\text { Kerja } \\
60 \%\end{array}$} & $\mathrm{C} 1$ & $\begin{array}{c}\text { Sasaran Kerja } \\
\text { Pegawai }\end{array}$ & $\begin{array}{l}\text { Core } \\
\text { Factor }\end{array}$ \\
\hline & $\mathrm{C} 2$ & Kegigihan & $\begin{array}{c}\text { Secondary } \\
\text { Factor }\end{array}$ \\
\hline \multirow{6}{*}{$\begin{array}{c}\text { Kriteria } \\
\text { Perilaku } \\
\text { Kerja } \\
40 \%\end{array}$} & C3 & $\begin{array}{l}\text { Orientasi } \\
\text { Pelayanan }\end{array}$ & $\begin{array}{l}\text { Core } \\
\text { Factor }\end{array}$ \\
\hline & $\mathrm{C} 4$ & Integritas & $\begin{array}{l}\text { Secondary } \\
\text { Factor }\end{array}$ \\
\hline & C5 & Komitmen & $\begin{array}{l}\text { Core } \\
\text { Factor }\end{array}$ \\
\hline & C6 & Disiplin & $\begin{array}{c}\text { Core } \\
\text { Factor }\end{array}$ \\
\hline & $\mathrm{C} 7$ & Kerjasama & $\begin{array}{l}\text { Secondary } \\
\text { Factor }\end{array}$ \\
\hline & $\mathrm{C} 8$ & $\begin{array}{l}\text { Kepemimpin } \\
\text { an }\end{array}$ & $\begin{array}{l}\text { Core } \\
\text { Factor }\end{array}$ \\
\hline \multicolumn{2}{|c|}{ rumus: $N C F=\frac{\sum N C}{\sum I C}$} & \multicolumn{2}{|r|}{ (2) } \\
\hline
\end{tabular}

Dari perhitungan core factor dan secondary factor berdasarkan kriteria sasaran kerja dan perilaku kerja diatas maka didapat hasil 
IN F ORMA T I K A

Jurnal Informatika, Manajemen dan Komputer, Vol. 12 No. 2, Desember 2020

eISSN : 2580-3042

pISSN : 1979-0694

nilai core factor dan secondary factor dari setiap pegawai dan subkriterianya seperti tabel berikut :

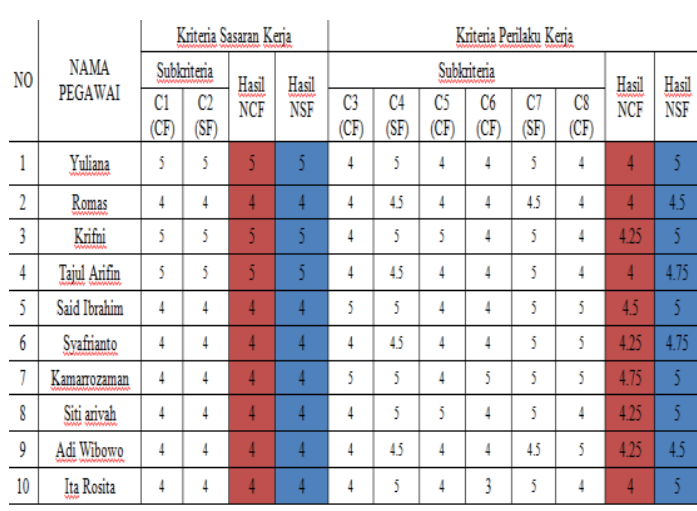

Gambar 4. Hasil NCF dan NSF

4. Perhitungan Nilai Total

Perhitungan nilai total pada Kriteria Sasaran Kerja dan Kriteria Perilaku Kerja dilakukan dengan rumus berikut :

$N=(x) \% N C F+(x) \% N S F$

Dari perhitungan nilai total diatas berdasarkan kriteria sasaran kerja dan perilaku kerja maka didapat nilai total dari setiap pegawai dan subkriterianya seperti tabel berikut :

\begin{tabular}{|c|c|c|c|c|c|c|c|}
\hline \multirow{2}{*}{ No } & \multirow{2}{*}{$\begin{array}{c}\text { NAMA } \\
\text { PEGAWAI }\end{array}$} & \multicolumn{3}{|c|}{$\frac{\text { Kintenia Sasaran Keja }}{60 \%}$} & \multicolumn{3}{|c|}{$\begin{array}{c}\text { Kintena Perilahu Keja } \\
40 \%\end{array}$} \\
\hline & & NCF & NSF & NSK & NCF & NSF & NPK \\
\hline 1 & Yuliana & 5 & 5 & 5 & 4 & 5 & 4.4 \\
\hline 2 & Romas & 4 & 4 & 4 & 4 & 4.5 & 42 \\
\hline 3 & Kiffi & 5 & 5 & 5 & 4.25 & 5 & 4.55 \\
\hline 4 & Tajul Arifin & 5 & 5 & 5 & 4 & 4.75 & 43 \\
\hline 5 & Said Ibrahim & 4 & 4 & 4 & 4.5 & 5 & 4.7 \\
\hline 6 & Srafinato & 4 & 4 & 4 & 4.25 & 4.75 & 4.45 \\
\hline 7 & Kamaroozaman & 4 & 4 & 4 & 4.75 & 5 & 4.85 \\
\hline 8 & Siti anivah & 4 & 4 & 4 & 4.25 & 5 & 455 \\
\hline 9 & Adi Wiborro & 4 & 4 & 4 & 4.25 & 4.5 & 435 \\
\hline 10 & Itra Rosita & 4 & 4 & 4 & 4 & 5 & 4.4 \\
\hline
\end{tabular}

Gambar 5. Nilai Total

5. Perhitungan Penentuan Ranking

Rumus perhitungan penentuan rangking seperti berikut ;

$$
\text { Rangking }=(x) \% N S K+(x) \% N P K
$$

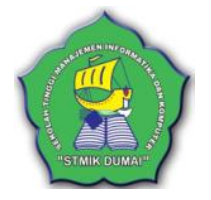

\begin{tabular}{|c|c|c|c|c|}
\hline NO & $\begin{array}{c}\text { NAMA } \\
\text { PEGAWAI }\end{array}$ & $\begin{array}{c}\text { NSK } \\
60 \%\end{array}$ & $\begin{array}{c}\text { NPK } \\
40 \%\end{array}$ & $\mathrm{R}$ \\
\hline 1 & Yuliana & 5 & 4.4 & 4.76 \\
\hline 2 & Romas & 4 & 4.2 & 4.08 \\
\hline 3 & Krifni & 5 & 4.55 & 4.82 \\
\hline 4 & Tajul Arifin & 5 & 4.3 & 4.72 \\
\hline 5 & Said Ibrahim & 4 & 4.7 & 4.28 \\
\hline 6 & Syafrianto & 4 & 4.45 & 4.18 \\
\hline 7 & Kamarrozaman & 4 & 4.85 & 4.34 \\
\hline 8 & Siti arivah & 4 & 4.55 & 4.22 \\
\hline 9 & Adi Wibowo & 4 & 4.35 & 4.14 \\
\hline 10 & Ita Rosita & 4 & 4.4 & 4.16 \\
\hline
\end{tabular}

Gambar 6. Data Perangkingan

\section{b. Tampilan Sistem}

\section{Tampilan Data Bagian}

Halaman ini digunakan untuk menampilkan data bagian yang ada didalam database. Data ini nantinya akan di gunakan sesuai kebutuhan sistem. Didalam tampilan data bagian dapat melakukan edit data bagian dengan cara :

a. Klik tombol edit jika ingin mengubah data atau menghapus data, dapat dilakukan ubah data sesuai kebutuhan dan klik tombol perbarui. Jika tidak melakukan ubah data dan akan menghapus data dapat klik tombol hapus.

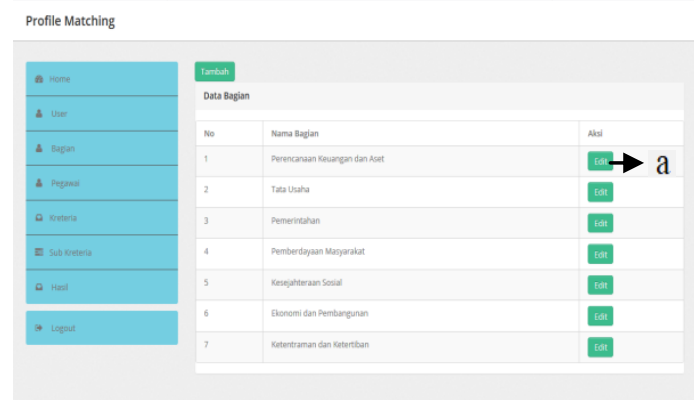

Gambar 7. Tampilan Data Bagian

\section{Tampilan Input Data Bagian}

Halaman ini digunakan untuk menginput data bagian ke dalam database dengan cara :

a. Masukkan data bagian sesuai kolom input yang tersedia

b. kemudian klik tombol simpan jika ingin menyimpan data.

c. Dan klik tombol kembali jika tidak melakukan penyimpanan data bagian 
IN F ORMA T I K A

Jurnal Informatika, Manajemen dan Komputer, Vol. 12 No. 2, Desember 2020

eISSN : 2580-3042

pISSN : 1979-0694

Profile Matching

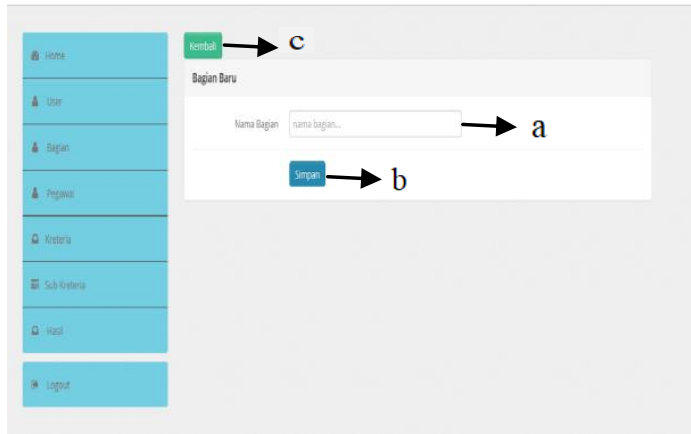

Gambar 8. Tampilan Input Data Bagian

\section{Tampilan Data Pegawai}

Halaman ini digunakan untuk menampilkan data pegawai yang ada didalam database. Data ini nantinya akan di gunakan sesuai kebutuhan sistem. Didalam tampilan data pegawai dapat melakukan edit data bagian dengan cara :

a. Klik tombol edit jika ingin mengubah data atau menghapus data, dapat dilakukan ubah data sesuai kebutuhan dan klik tombol perbarui. Jika tidak melakukan ubah data dan akan menghapus data dapat klik tombol hapus.

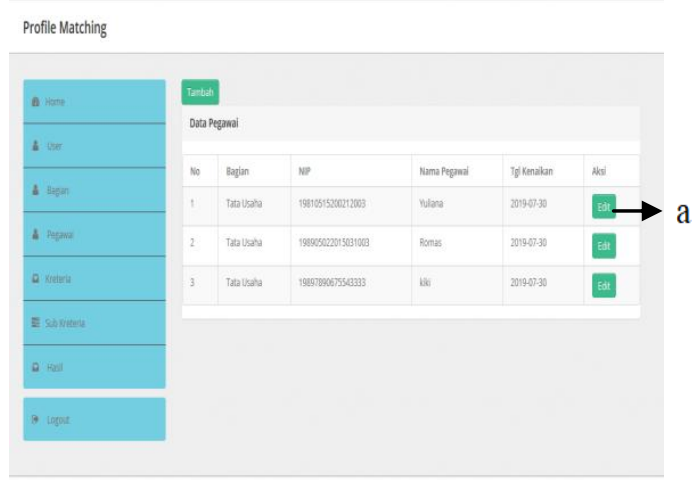

Gambar 9. Tampilan Data Pegawai

\section{Tampilan Input Data Pegawai}

Halaman ini digunakan untuk menginput data pegawai kedalam database dengan cara :

a. Masukkan data pegawai sesuai kolom input yang tersedia

b. Combo box digunakan untuk memilih data bagian, kemudian klik tombol simpan jika ingin menyimpan data.

c. Dan klik tombol kembali jika tidak melakukan penyimpanan data pegawai
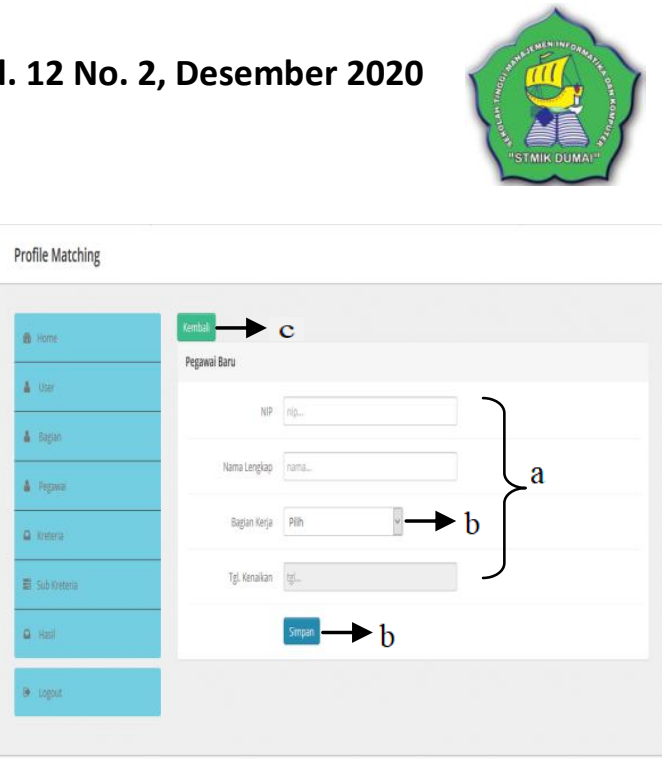

Gambar 10. Tampilan Input Data Pegawai

\section{Tampilan Data Kriteria}

Halaman ini digunakan untuk menampilkan data kriteria yang ada didalam database. Data ini nantinya akan diproses sesuai kebutuhan sistem. Didalam tampilan data kriteria dapat melakukan edit dan hapus data kriteria dengan cara :

a. Klik tombol edit jika ingin mengubah data, kemudian setelah masuk ke form edit, ubah data sesuai kebutuhan dan kllik tombol perbarui.

b. Klik tombol hapus semua kreteria jika ingin menghapus data.

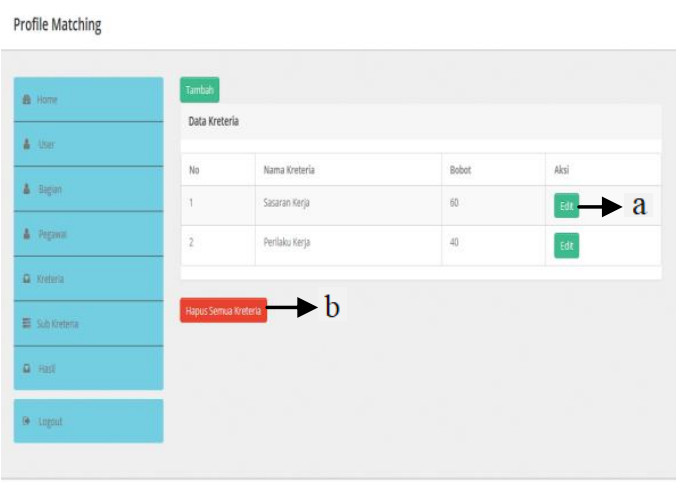

Gambar 11. Tampilan Data Kriteria

\section{Tampilan Input Data Kreteria}

Halaman ini digunakan untuk menginput data kriteria kedalam database dengan cara sebagai berikut:

a. Masukkan data kreteria sesuai kolom input yang tersedia

b. kemudian klik tombol simpan jika ingin menyimpan data.

c. Dan klik tombol kembali jika tidak melakukan penyimpanan data kreteria. 
IN F ORMA T I K A

Jurnal Informatika, Manajemen dan Komputer, Vol. 12 No. 2, Desember 2020

eISSN : 2580-3042

pISSN : 1979-0694

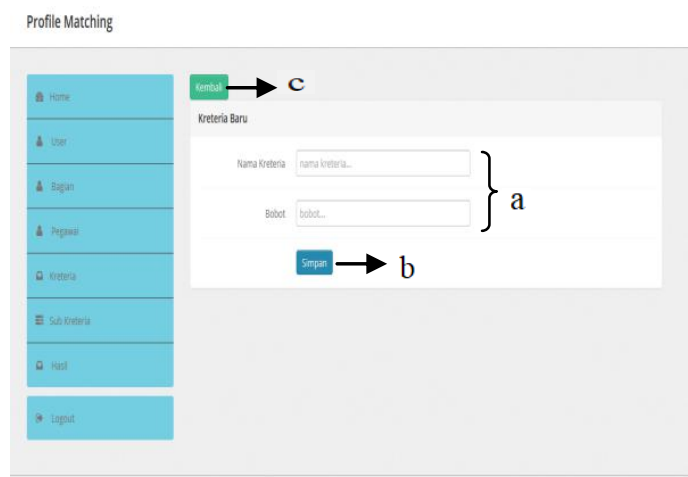

Gambar 12.Tampilan Input Data Kreteria

\section{Tampilan Data Sub Kreteria}

Halaman ini digunakan untuk menampilkan data sub kreteria yang ada didalam database. Data ini nantinya akan di gunakan sesuai kebutuhan sistem. Didalam tampilan data sub kreteria dapat melakukan edit data bagian dengan cara berikut:

a. Klik tombol edit jika ingin mengubah data atau menghapus data, dapat dilakukan ubah data sesuai kebutuhan dan klik tombol perbarui. Jika tidak melakukan ubah data dan akan menghapus data dapat klik tombol hapus.

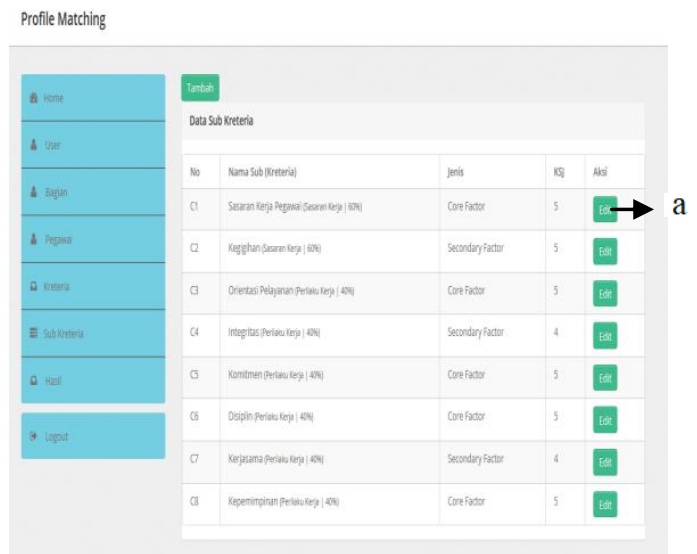

Gambar 13. Tampilan Data Sub Kreteria

\section{Tampilan Input Data Sub Kreteria}

Halaman ini digunakan untuk menginput data sub kreteria kedalam database dengan cara :

a. Masukkan data sub kreteria sesuai kolom input yang tersedia

b. Combo box digunakan untuk memilih data Kreteria dan jenis sub kreteria, kemudian klik tombol simpan jika ingin menyimpan data.

c. Dan klik tombol kembali jika tidak melakukan penyimpanan data pegawai
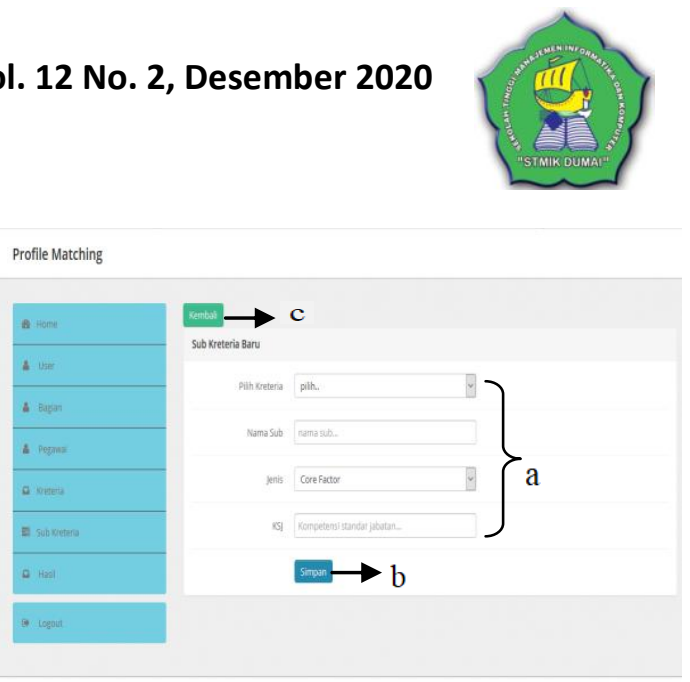

Gambar 14. Tampilan Input Data Sub Kreteria

\section{Tampilan Data Proses}

Halaman ini digunakan untuk menampilkan data Proses yang ada didalam database. Data ini nantinya akan diproses sesuai kebutuhan sistem. Didalam tampilan data proses dapat melakukan usulkan dengan cara :

a. Untuk pegawai yang sudah 4 tahun dapat melakukan pengusulan dengan klik tombol usulkan

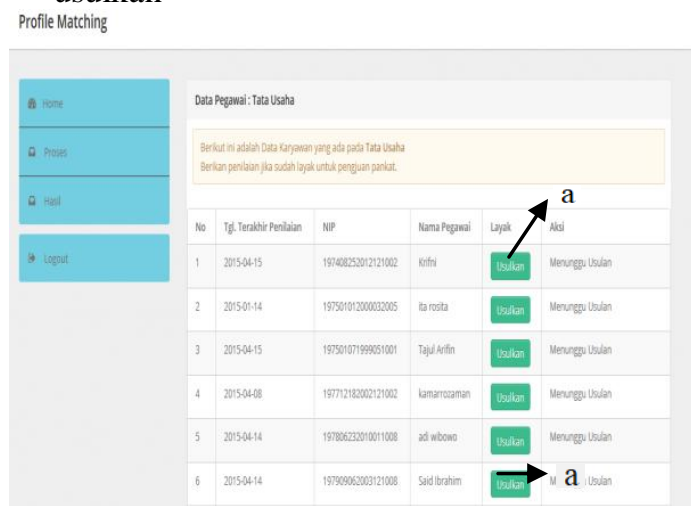

Gambar 15. Tampilan Data Proses

\section{Tampilan Input Data Proses}

Halaman ini digunakan untuk menginput data proses yaitu penilaian kedalam database dengan cara :

a. Masukkan data proses yang berisi nilai sesuai kolom input yang tersedia.

b. kemudian klik tombol simpan jika ingin menyimpan data.

c. Dan klik tombol kembali jika tidak melakukan penyimpanan data proses tersebut. 
IN F O R M A I I A

Jurnal Informatika, Manajemen dan Komputer, Vol. 12 No. 2, Desember 2020

eISSN : 2580-3042

pISSN : 1979-0694

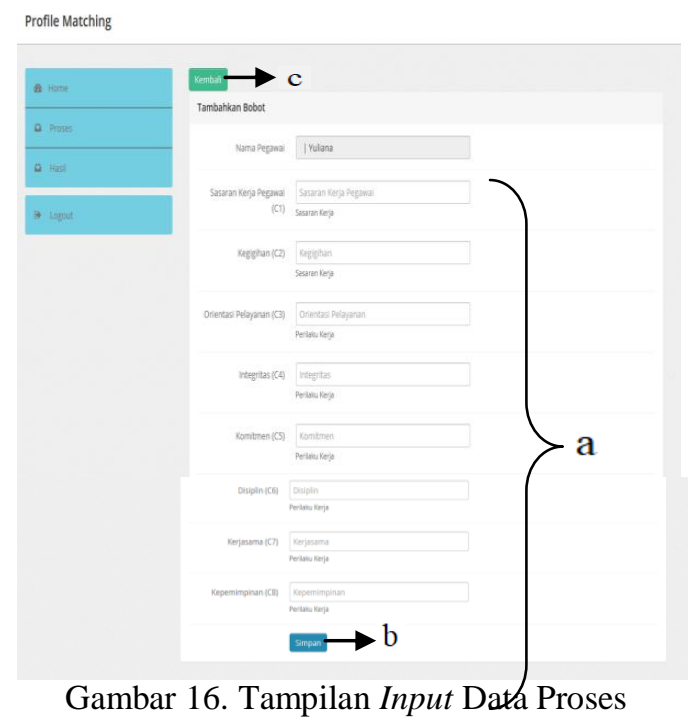

11. Tampilan Laporan Data Penilaian

Halaman ini digunakan untuk menampilkan laporan data penilaian yang akan dicetak.

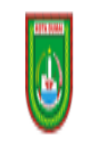

$$
\begin{aligned}
& \text { PEMERINTAHAN KOTA DUMAI } \\
& \text { KECAMATAN SUNGAI SEMBILAN } \\
& \text { JALAN RAYA LUBUKGAUNG } \\
& \text { DUMAL-RIAU }
\end{aligned}
$$

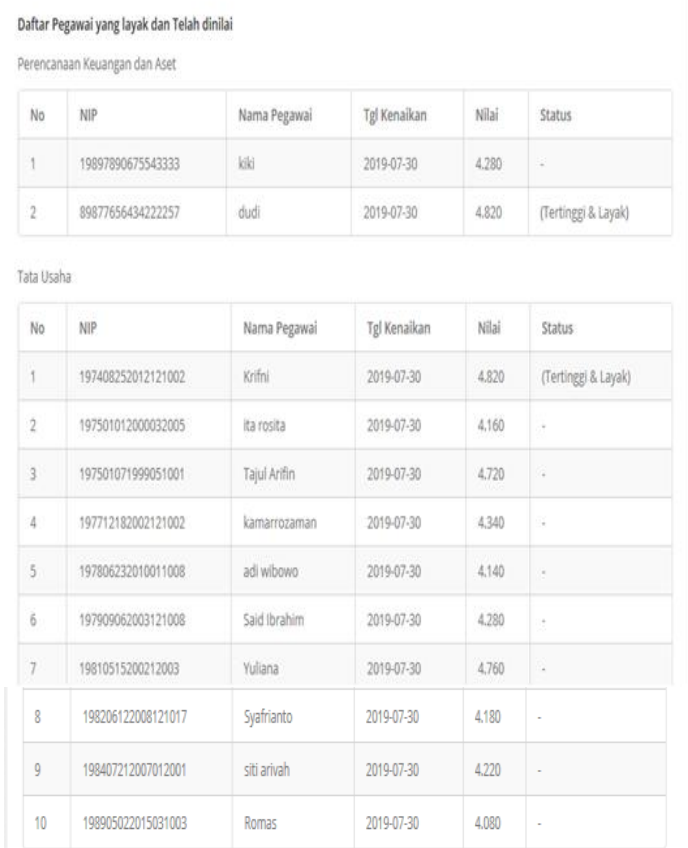

Gambar 17. Tampilan Laporan Data Penilaian

1. Dengan adanya sistem ini bisa melakukan pengolahan data menggunakan metode Profile Matching.

2. Diharapkan dengan adanya sistem ini dapat membantu proses penilaian kriteria pegawai yang akan melakukan pengusulan kenaikan pangkat pada Kantor Camat Sungai Sembilan. Dan dapat dapat meminimalisir ketidakakuratan penilaian criteria.

3. Diharapkan hasil dari penilaian menggunakan metode Profile Matching dapat memberikan kemudahan dalam pembuatan laporan penilaian pegawai yang akan melakukan pengusulan kenaikan pangkat.

\section{REFERENSI}

Artoni. (2006). Sistem Pendukung Keputusan Kenaikan Pangkat Untuk Jabatan Fungsional Berdasarkan Permohonan Pada Penyuluh Keluarga Berencana Di Pemerintah Daerah Kecamatan Danurejan Kota Yogyakarta. Progresif, 2(2), 166-226. Dahlan, M. (2013). Membuat Web dengan PHP.

Eli Tri Sulis Setia Rini, N. (2018). Aplikasi Pengajuan Beasiswa Berbasis Web pada Kantor Walikota Bagian Administrasi Kesejahteraan Rakyat (KESRA) Dumai. Jurnal BETRIK, 013(01), 16-23.

Erdawati, Arie Linarta, Sukri Adrianto, putri yunita. (2016). I n f o r m a t i k a. Sistem Pendukung Keputusan Penilaian Dosen Berkualitas Di Stmik Dumai Menggunakan Metode Simple Additive Weighting, 8(2), 55-63.

Idria Maita, A. H. (2011). Iplementasi Sistem Informasi Kenaikan Pangkat Dosen dan Pegawai di UIN Suska Riau. SNTIKI, III(III), 334-341.

Ignas. (2014). Sistem InformasiPenjualan Online untuk Tugas Akhir.

Kadir, A. (2014). Pengenalan Sistem Informasi Edisi Revisi.

Kristiana, T. (2015). Penerapan Profile Matching Untuk Penilaian Kinerja Pegawai Negeri Sipil (Pns). Jurnal Pilar Nusa Mandiri Vol. XI, No.2 September 2015 PENERAPAN, 11(2), 161-170.

Priyanto Hidayatullah, J. K. K. (2014). Pemrograman WEB.

Setiawan, D. (2018). Buku Sakti Pemrograman Web.

\section{KESIMPULAN}

Dari hasil analisis dan penelitian yang telah dilakukan, maka dapat diambil kesimpulan sebagai berikut : 